A RCHIWA, BIBLIOTEKI

I MUZEA KOŚCIELNE 112 (2019)

https://doi.org.10.31743/abmk.2019.112.14

BEATA OSTRÓWKA SAC* - GDAŃSK

\title{
ZESPÓŁ DWORSKO-PARKOWY W RAJCY. PRZYCZYNEK DO HISTORII POLSKIEJ PROWINCJI SIÓSTR MISJONAREK APOSTOLSTWA KATOLICKIEGO (PALLOTYNKI)
}

\begin{abstract}
Streszczenie
Artykuł przedstawia zespół dworsko-parkowy w malowniczo położonej miejscowości Rajca, pomiędzy Nowogródkiem a Baranowiczami na terenie dzisiejszej Białorusi. Właścicielami miejscowości byli Dunin-Rajeccy z Koszelewa. Wznieśli oni dwór klasycystyczny z otaczającymi go budynkami gospodarczymi w XVIII-XIX w. Wokół dworu rozciągały się cztery hektary ziemi, które stanowiły park regularno-krajobrazowy oraz sad i ogród warzywny. Córka Franciszka Dunin-Rajeckiego, Ludwika, odziedziczyła Rajcę i wniosła jako wiano do rodziny Wereszczaków, poślubiając Józefa, młodszego brata Maryli, młodzieńczej miłości Adama Mickiewicza. Z tym ożenkiem związany był gruntowny remont dworu ok. poł. XIX w.
\end{abstract}

Kolejny właściciel, Franciszek Wereszczaka w 2. poł XIX w. przekształcił stary drzewostan wokół dworu w piękny park regularno-krajobrazowy, który stanowił największą wartość całego majątku. Po jego śmierci Rajca przeszła w ręce Puttkamerów i Żółtowskich. Ostatni właściciel hrabia Adam Żółtowski, wykładowca filozofii na Uniwersytecie Poznańskim, oddał majątek Księżom Pallotynom, a ci odsprzedali go Siostrom Pallotynom, które do momentu usunięcia przez wojsko niemieckie w 1943 r. były właścicielkami majątku.

Jest to typowy polski dwór klasycystyczny, jednak jeden z niewielu drewnianych zachowanych na tych terenach. Przy wjeździe do majątku, po prawej stronie od bramy, była usytuowana najprawdopodobniej XIX w. empirowa, bardzo wydłużona oficyna, która była uważana za starszą od dworu. Pośród zabudowy w majątku znajdowały się również budynki gospodarcze: stajnia, wozownia, spichlerz, stodoła, dom w ogrodzie, które zostały spalone w czasie wojny w 1943 r. wraz z oficyną. Pozostał jedynie zniszczony i nieco przebudo-

* Beata Ostrówka SAC - mgr historii sztuki; Archiwistka Prowincjalna Polskiej Prowincji Zgromadzenia Sióstr Misjonarek Apostolstwa Katolickiego (Siostry Pallotynki) e-mail: beata_pall@op.pl

https://orcid.org./0000-0002-4489-4929 
wany dwór otoczony zniszczonym również parkiem i słup kamienny z herbem Dunin-Rajeckich, Łabędź, z koroną i łabędziem w klejnocie, na końcu alei w parku.

Słowa kluczowe: Rajca; Nowogródek; siostry pallotynki; księża pallotyni; Dunin-Rajeccy

Pomiędzy Nowogródkiem a Baranowiczami, kilkanaście kilometrów od Jeziora Świteź, na terenie dzisiejszej Białorusi, wśród lasów i pól, jarów i pagórków, natrafiamy na malowniczo położoną miejscowość Rajca (we wcześniejszym brzmieniu Rajce). Tam właśnie znajdował się otoczony parkiem dwór wraz z zabudowaniami gospodarczymi, przy którym chciałam się chwilę zatrzymać, prześledzić losy, poznać właścicieli, może odrobinę zasmakować klimatu życia dworskiego. Popatrzmy również na zmiany, jakie dokonywały się w obrębie dworu i całego majątku na przestrzeni lat.

Sięgnęłam do różnych źródeł. Niewiele jednak o Rajcy napisano. Najistotniejszy w historii obiektu był dla mnie czas, kiedy majątek należał do sióstr pallotynek. Zgromadzenie Sióstr Misjonarek Apostolstwa Katolickiego stawiało wówczas pierwsze kroki na polskiej ziemi. Rajca to pierwszy dom, jakby „kolebka” Polskiej Prowincji Zgromadzenia, choć siostry podzieliły los repatriantów ${ }^{1}$ po zakończeniu II wojny światowej i osiadły w Gdańsku.

Zaledwie dziewięć lat siostry zamieszkiwały rajecki dwór. Próbowały przywrócić miejscowości dawną świetność po latach wojen. Ledwie zdołały przystosować budynki do nowej roli - klasztoru i w pewnym sensie placówki misyjnej wśród prawosławia, a na nowo zaczęły się działania wojenne.

Większość informacji z pobytu sióstr w Rajcy to wspomnienia, ale są też dokumenty. Bardzo pomocne okazały się sprawozdania, pisane co pół roku do przełożonych wyższych, do Limburga. To z nich dowiadujemy się o przebudowach i zmianach, które miały miejsce w latach przedwojennych.

W wydawanej przez Księży Pallotynów „Królowej Apostołów i Apostole” i „Apostoł wśród świata”, można znaleźć artykuły mówiące o obecności i pracy sióstr w Rajcy.

W Archiwum Polskiej Prowincji Sióstr Pallotynek znajdują się fotografie, które pozwalają zobaczyć całość nieistniejącego już założenia w Rajcy, a także ślady wydarzeń z ostatnich lat przed wojną.

\section{Historia}

Nie sięgając daleko, w XVIII i na początku XIX wieku właścicielami tej urokliwie położonej miejscowości byli potomkowie jednej z gałęzi wielkiego rodu Duninów herbu Łabędź. Potomkowie już od XIV wieku zaczęli używać przydomków dodawanych do nazwiska, dla odróżnienia gałęzi rodu, a stworzonych od nazwy miejscowości, w której osiedli. Tak powstali m.in. Dunin-Rajeccy z Raj-

${ }^{1}$ W Archiwum Polskiej Prowincji Sióstr Pallotynek (dalej: APP) znajdują się dokumenty repatriacyjne. W zasobach archiwum znajduje się również zaświadczenie, że wymienione w nim siostry są członkiniami zgromadzenia. Poświadczył podpisem i pieczęcią ks. Wiktor Kulukas, proboszcz w Worończy, który bywał często w Rajcy. 
ca, koło Radomia. Przedstawiciele tej właśnie gałęzi osiedli w okolicach Wilna i Nowogródka. Byli majętni. Poza majątkiem we wsi Rajca, posiadali również: Koszelewo, Puźniewicze, Niańków, Miratycze i kilka folwarków.

W XVIII wieku jeden z członków rodu Duninów-Rajeckich wziął udział w powstaniu kościuszkowskim na Litwie ${ }^{2}$. Byli także delegaci na sejmach i elektorzy ${ }^{3}$. Ostatni zaś znany właściciel Rajcy, Franciszek, był nazywany potomkiem Sejmu Czteroletniego.

W niewielkiej odległości od dworu, już poza terenem otaczającym dwór, właściciele ufundowali kościól. Wiemy jedynie, że w zamyśle donatora był świątynią katolicką. Jednak od połowy XIX wieku należy do Kościoła prawosławnego i służy wiernym jako cerkiew św. Barbary.

XIX-wieczny rysownik i akwarelista, Napoleon Orda, podczas podróży po guberniach we Wschodniej Polsce, w rysunkach i akwarelach utrwalił ogromną liczbę kościołów, pałaców, dworów i pejzaży. Nie ominął w swych podróżach także Rajcy. Jedna z akwarel przedstawia kościół w tej miejscowości. Na kartonie umieścił napis informujący, iż kościół został odbudowany w 1816 roku przez pułk. Konstantego Dunin-Rajeckiego, a fundowany przez Dunin-Rajeckich już w XVI wieku ${ }^{4}$

W tym samym czasie brat Konstantego, wspomniany już Franciszek (1780?), marszałek szlachty nowogródzkiej, przebywał głównie w Koszelewie. Tamten dwór obrał za siedzibę. Przebudował go w pierwszej połowie XVIII wieku na większy i wygodniejszy5. Ożenił się z Barbarą Mierzejewską (1780-?) i doczekał $\mathrm{z}$ nią trzech córek i syna.

Powróćmy jednak do Rajcy. Ludwika (1810-?), najstarsza córka Franciszka, odziedziczyła majątek i wniosła go jako wiano do rodziny Wereszczaków, poślubiając marszałka nowogródzkiego Józefa Wereszczakę (1790-1871), herbu Kościesza. Był on młodszym bratem Maryli (Marianny Ewy) Wereszczakówny, ukochanej Adama Mickiewicza z lat młodzieńczych ${ }^{6}$.

Wereszczakowie zamieszkiwali w Tuhanowiczach. To właśnie tam w rodzinnym majątku spotykało się na wakacjach grono przyjaciół, tj. Wereszczakowie,

${ }^{2}$ „W 1794 r., podczas powstania kościuszkowskiego, pod Rajcą, niewielka grupa powstańczej partyzantki pod dowództwem właściciela miejscowego majątku - nieznanego z imienia Rajeckiego, zaatakowała oddział dragonów rosyjskich z korpusu gen. Wasilija Łanskoja. Po dłuższej wymianie ognia powstańcy wycofali się do lasu. W boju zginęło kilku Rosjan i kilku powstańców, w tym m.in. dowódca oddziału Rajecki”. G. Rąkowski, Dwór w Rajcy, www.kresy.pl/kresopedia/turystyka/ dwor-w-rajcy (dostęp: 22.02.2018).

${ }^{3}$ https://books.google.pl/books?itd=5glfAAAAcAAJ (dostęp: 09.04.2018), Poczet postów z Woj. Nowogródzkiego i Lidzkiego itp.

${ }^{4}$ Napoleon Orda, Rajce. Kościół /Cerkiew/ św. Barbary.1864-1876. Rys. ołówkiem podmalowany akwarelą. Muzeum Narodowe, Kraków. III - r.a. 4495. (Teka Mińska); W opisie pojawia się nazwisko Franciszka Wereszczaki. Według podanych lat był on wówczas właścicielem Rajcy; www. pinakoteka.zascianek.pl/Orda/Index.htm (dostęp: 28.02.2018).

${ }^{5}$ T. Krzywicki, Szlakiem Adama Mickiewicza po Nowogródczyźnie, Wilnie i Kownie, Przewodnik; https://books.google.pl/books?isbn=8389188511 (dostęp: 10.03.2018).

${ }^{6}$ M. Zielińska, Opowieść o Gustawie i Maryli. Czyli Teatr, życie i literatura, Warszawa 1998, s. 52 i nn. 
Wawrzyniec Puttkamer ${ }^{7}$, Adam Mickiewicz, Tomasz Zan ${ }^{8}$ i inni. Młodemu towarzystwu z Wilna imponował zapewne klimat Tuhanowicz swoją beztroską, rozmachem, nieustanną zabawą i gośćmi, dla których dom był nieustannie otwarty. Często wakacje spędzali razem na rozmowach, lekturze i zabawach. Czuli się dobrze w swoim towarzystwie, o czym świadczy np. krótki list w formie wiersza pisany wspólnie przez A. Mickiewicza, W. Puttkamera i J. Wereszczakę do T. Zana ${ }^{9}$, w którym trójka przyjaciół z tęsknotą oczekuje przyjazdu towarzysza letnich przygód. Przyjeżdżali na zaproszenie Michała Wereszczaki (1795-1857) najstarszego brata Maryli i Józefa, którego znali ze studiów. Później, gdy przez pewien czas (do 1821 r.) Michał mieszkał w Płużynach sąsiadujących z Rajcą, organizował zabawy dla przyjaciół nad Jeziorem Świteź. Po jednej z takich wypraw pozostał trwały ślad w twórczości A. Mickiewicza ${ }^{10}$.

Nieco inna relacja łączyła Marylę Wereszczakównę z Adamem Mickiewiczem. Przyjaźń, która szybko przerodziła się w romantyczną miłość, niespełnioną jednak, ale owocną, jeśli chodzi o twórczość poety. Maryla stała się jego muzą. Była jednak zaręczona z Wawrzyńcem Puttkamerem, herbu Bradacice, którego A. Mickiewicz podziwiał i szanował. Mimo nadziei, która wcześniej towarzyszyła poecie, Maryla poślubiła W. Puttkamera, wyjechała z Tuhanowicz i zamieszkała w Bolciennikach. Adam Mickiewicz zaś, mówiąc w wielkim skrócie, napisał IV część Dziadów i tak ukazał tę miłość światu ${ }^{11}$.

Józef Wereszczaka, najmłodszy z rodzeństwa, osiedlił się natomiast w Rajcy z poślubioną sobie Ludwiką. Co nastąpiło zapewne później, gdy część przyjaciół znalazła się na emigracji. W tym czasie bądź zaraz po ich osiedleniu nastąpił remont dworu rajczańskiego ${ }^{12}$.

Spadkobiercą Józefa i Ludwiki w kwestii Rajcy został Franciszek Wereszczaka (1840-1897?), najmłodszy z czwórki dzieci.

${ }^{7}$ Wawrzyniec Puttkamer był człowiekiem wykształconym. Ukończył fakultet matematyczno-fizyczny w Wilnie. Oczytany w literaturze najnowszej, rozmiłowany w muzyce i sztukach pięknych. W 1812 r. zaciągnął się do armii Napoleona i jako zwykły żołnierz ruszył na Moskwę. Walczył pod Berezyną, Esterą i Lipskiem. Jako ranny dostał się do pruskiej niewoli. Na sejmikach szlacheckich walczył o uwolnienie chłopów z poddaństwa. P. Chmielowski, Kobiety Mickiewicza, Słowackiego i Krasińskiego. Zarys literacki, Warszawa 1886; www.edusens.pl/.../wawrzyniec-puttkamer-rywalem-czy-raczej-idolem-mickiewicza (dostęp: 20.03.2018).

${ }^{8}$ Tomasz Zan, późniejszy organizator filaretów. On również darzył uczuciem Marylę. Zielińska, Opowieść o Gustawie i Maryli, s. 46-47, 183.

${ }^{9}$ Tamże, s. 35-36.

${ }^{10}$ Michał, najstarszy z trojga rodzeństwa. Wielki znawca historii Polski i Litwy. Znał dobrze herbarze i losy rodzin polskich. Miał zbiory broni, hełmów, pancerzy - niektóre z nich pamiętały bitwę pod Grunwaldem. Posiadał ogromną bibliotekę i znaną w okolicy oranżerię. Znany był z nietuzinkowych pomysłów. Mógł więc zorganizować wyprawę po Świteziankę, którą opisał A. Mickiewicz w Świtezi i zadedykował Michałowi. Później jeszcze w swojej twórczości na obczyźnie powracał do klimatu dworków na Litwie, np. w księgach Pana Tadeusza. P. Chmielowski, Adam Mickiewicz, Zarys biograficzno-literacki, Warszawa 1898; I. Meger, Ktokolwiek będziesz w nowogródzkiej stronie. Początki sióstr Pallotynek na ziemiach polskich, „Miejsca Święte”, (2010) nr 1 (157), s. 6-13.

${ }^{11}$ Wereszczakówna Maryla, w: Nowa Encyklopedia Powszechna PWN, t. 6, red. B. PetrozolinSkowrońska, Warszawa 2004, s. 698.

${ }^{12}$ I. Meger podaje iż dwór został gruntownie odnowiony w latach 50. XIX w. 
Franciszek był to człowiek wielkiej zacności i nosił piękno niemałej kultury w duszy artystycznej, a będąc jednocześnie zawołanym amatorem ogrodnictwa, w krótkim przeciągu czasu upiększył Rajcę niedopoznania ${ }^{13}$.

Ponieważ Franciszek był bezdzietny, po jego śmierci pretendentami do majątku zostali: wdowa po zmarłym i brat Kazimierz, a także siostrzenica Józefa Tuchanowska. Urażony takim obrotem spraw brat zmarłego sprzedał Rajcę w 1897 roku Wawrzyńcowi Puttkamerowi, wnukowi Maryli z Wereszczaków Puttkamerowej $^{14}$. Wdowa po Franciszku wywiozła zaś całe wyposażenie dworu ${ }^{15}$.

Nowy właściciel mieszkał stale w powiecie lidzkim, w Bolciennikach, gdzie wybudował nowy dwór w stylu gotyku angielskiego ${ }^{16}$. Rajcą raczej mało się interesował, a majątek zamieszkały zapewne przez dzierżawcę zaczął podupadać.

W 1910 roku Rajcę odziedziczyła jedna z córek Wawrzyńca, Janina Maria (1889-1968), która wyszła za mąż za Adama hr. Żółtowskiego (1881-1958) ${ }^{17}$ herbu Ogończyk z Niechanowa w Wielkopolsce i wyjechała do Poznania, gdzie Adam był profesorem filozofii na Uniwersytecie im. Adama Mickiewicza. Rajca była ich letnią siedzibą, przyjeżdżali tu raczej rzadko. W odziedziczonych po Putkamerach majątkach na kresach przebywali do 1918 r., do odzyskania niepodległości. Tylko na krótko w 1918 roku wyjeżdżali do Warszawy i Krakowa ${ }^{18}$. Gdy odziedziczyli majątek, dwór był pusty. Wyposażyli go w sprzęty proste, robione przez miejscowych stolarzy, czasem na wzór angielski, które nie miały większej wartości artystycznej ${ }^{19}$.

W czasie wojen 1914-1918 i 1919-1920 dwór został zdewastowany przez stacjonujące w okolicy wojsko. W 1933 roku właściciele przenieśli się na stałe z Poznania do Bolciennik, gdy władze ministerialne odebrały Adamowi katedrę uniwersytecką, a w 1939 roku wyjechali już na stałe do Anglii ${ }^{20}$.

Na rok przed przeprowadzką do Bolciennik, w 1932 roku oddali Rajcę Księżom Pallotynom. Była to resztówka po parcelacji większego majątku ${ }^{21}$, tj. 60 ha

${ }^{13}$ W. Slizień, Przeczytajmy to jeszcze raz. Wieś Ilustrowana - u kolebki wieszcza, „Wieś Ilustrowana”, Warszawa 1911 r., Nr 9, Artykuł napisany w Mińsku w sierpniu 1911 r. i opatrzony fotografiami z własnej teki. Fotografia dworu może być wcześniejsza niż Jana Bułhaka. Autor wspomina czas gdy Rajcę bardzo ozdobił Franciszek Wereszczaka. Być może autor pamiętał te czasy. A jest prawdopodobne, że znał Franciszka Wereszczakę osobiście. http://cbr.gov.pl/rme-archiwum/2010/ rme37/dane/9_4.html, (dostęp: 28.02.2018)

${ }^{14}$ R. Aftanazy, Dzieje rezydencji na dawnych kresach Rzeczypospolitej, t. 2, województwa brzesko-litewskie, nowogródzkie, Wrocław 1992, s. 325-326.

${ }^{15}$ Tamże.

${ }^{16}$ Dwór został wzniesiony w latach 1890-1896, według projektu Tadeusza Roztworowskiego, www.pl.wikipedia.org/wiki/Bolcieniki (dostęp: 03.04.2018).

${ }^{17}$ Filozof i historyk. Po 1939 r. wyjechał do Wielkiej Brytanii i założył w 1940 r. Polski Ośrodek Naukowy w Londynie i został jego dyrektorem. Prof. Polskiego Uniwersytetu na Obczyźnie w Londynie. Wiceprezes Rady Naczelnej Polskiego Związku Ziem Zachodnich. Wydał wiele rozpraw filozoficznych. Żóltowski Adam (1881-1958), w: Nowa Encyklopedia Powszechna, t. 6, red. B. Petrozolin-Skowrońska, Warszawa 2004, s. 1085.

${ }^{18}$ Związek Rodu Żółtowskich, Adam Żółtowski /1881-1958/, „Kwartalniki”, 6-8 (1995);

www.zoltowscy.pl/wp/1995/06/adam-zoltowski-1881-1958/(dostęp:10.03.2018).

${ }^{19}$ Aftanazy, Dzieje rezydencji na dawnych kresach, s. 325-326.

${ }^{20}$ Źóltowski (1881-1958) Adam, w: Nowa Encyklopedia Powszechna PWN, s. 1085.

${ }^{21}$ APP, „Apostoł wśród świata”, Rocznik VII, Warszawa 1935, z. 1, s. 17. 
ziemi wraz z zabudowaniami. Jak się okazało, teren nie nadawał się na rozwinięcie szerokiej działalności duszpasterskiej. Widoczne jednak były potrzeby pracy charytatywnej, a przede wszystkim niezbędny był ośrodek życia katolickiego, który promieniowałby na okolicę. Niewielki procent ludności na tych terenach stanowili katolicy ${ }^{22}$. Było to miejsce, którym mogły zając się Siostry Pallotynki Misjonarki i bardzo dobrze taką rolę wypełnić.

Przez wiele lat ks. Alojzy Majewski, pallotyn, który przyczynił się, by do Polski sprowadzić księży i braci pallotynów, kierował zaproszenie do Niemiec, do Limburga, by siostry pallotynki podjęły pracę w Polsce. Gdy cała sprawa zaczęła nabierać realnych kształtów, w czerwcu 1933 roku przyjechały pierwsze siostry pallotynki, by obejrzeć posiadłość w Rajcy ${ }^{23}$ po hrabiach Żółtowskich, którą księża zaproponowali odsprzedać. Do podpisania umowy doszło 5 lipca $1933 \mathrm{roku}^{24}$. Dnia 2 lutego 1934 roku siostry przyjechały już na dłużej i przejęły posiadłość od pallotynów 12 kwietnia tego roku ${ }^{25}$.

Do wybuchu wojny w 1939 roku siostry zajmowały dwór, oficynę i wszystkie przyległe budynki gospodarcze. Dbały o park i całe gospodarstwo. Nie tylko siostry, ale również księża pallotyni dbali o to, by dziewczęta chętne do życia zakonnego mogły poznać siostry pallotynki i często w Królowej Apostołów umieszczali informacje o Zgromadzeniu ${ }^{26}$. Dzięki temu spora liczba kandydatek zgłaszała się do Rajcy, chcąc podjąć życie zakonne. Liczba powołań wymusiła podjęcie przebudowy wewnątrz dworu i remont oficyny, która stała się mieszkaniem dla najmłodszych kandydatek. W niej mieściło się również przedszkole, pokój gościnny i pomieszczenia przystosowane do pracy: szwalnia, pralnia itp.

Gdy wyprowadził się dzierżawca w 1935 roku, który zajmował część oficyny, przystosowano te pomieszczenia na kaplicę dla wiernych. Było ono jednak zbyt małe, by zaspokoić potrzeby wiernych przybywających z okolicznych miejscowości. Jeszcze jesienią tego samego roku przekształcono na kaplicę murowany spichlerz, który temu celowi służył do wojny. Od 1935 roku w Rajcy znajdował się samochód, nazywany przez siostry żartobliwie samochodem „misyjnym”. Sprowadził go ks. Stanisław Wierzbica od ofiarodawców z Chorzowa. Auto rzeczywiście służyło apostolstwu, szczególnie w sprawach katechizacji i pomocy chorym $^{27}$.

${ }^{22}$ Z naszych domów misyjnych, „Królowa Apostołów”, (1933) nr 11, s. 301-303.

${ }^{23}$ Archiwum Domu Księży Pallotynów w Ołtarzewie. Kronika Domu Księży Pallotynów w O1tarzewie, 14-16 czerwca $1933 \mathrm{r}$.

${ }^{24} \mathrm{~W}$ Archiwum Sióstr Pallotynek znajduje się thumaczenie umowy zawartej pomiędzy Stowarzyszeniem Księży Pallotynów i Zarządem Generalnym Sióstr Pallotynek, który mieścił się wówczas w Limburgu nad Lahnem zawartej 5 lipca $1933 \mathrm{r}$.

${ }^{25}$ Streszczenie rajczańskich sprawozdań, s. 2

${ }^{26}$ Wiele starszych sióstr, które już zmarły, jeszcze kilka lat temu wspominały, że dowiedziały się o Zgromadzeniu z „Królowej Apostołów”.

${ }^{27}$ Streszczenie rajczańskich sprawozdań, s. 8. 


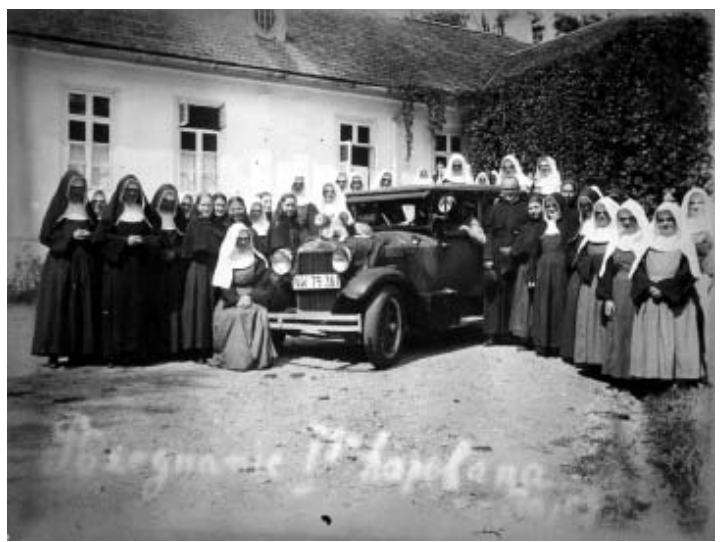

Il.1. Pożegnanie ks. kapelana Stanisława Wierzbicy latem 1936 r., autor nieznany, z albumu S.M. Pauli Moniki Buchwald, Archiwum Polskiej Prowincji Sióstr Pallotynek.

Na uroczystości kościelne, które były wpisane w życie sióstr i okolicznej ludności przyjeżdżali państwo Żółtowscy mieszkający w Bolciennikach i Balińscy z Sienieżyc ${ }^{28}$. Byli oni nie tylko gośćmi. Wspierali nieustannie siostry, które żyły bardzo skromnie, i prowadzone przez nie dzieła apostolskie. Częstym gościem był proboszcz z Worończy, ksiądz Wiktor Kulukas i ksiądz prałat Michał Dalecki, który w czasie wojny został rozstrzelany w Nowogródku ${ }^{29}$.

Gdy wybuchła wojna, 1 września 1939 roku w Rajcy było jeszcze spokojnie, ale gdy wojska rosyjskie przekroczyły granice Polski 17 września, zaczęły się prześladowania i wywózka ludności na Syberię. Siostry też musiały liczyć się z koniecznością opuszczenia Rajcy. Rzeczywiście wspólnota uległa rozproszeniu. Część sióstr wróciła do swoich rodzin, inne szukały utrzymania jako pomoc domowa bądź pracy w różnych ośrodkach ${ }^{30}$. Dla bezpiecznego prowadzenia pracy siostry podjęły decyzję przywdziania stroju świeckiego.

W 1940 roku siostry musiały opuścić dom. Dnia 2 lutego została zlikwidowana kaplica, a w marcu ks. kapelan wyjechał do Płonki Kościelnej, gdzie już wcześniej kilka sióstr znalazło schronienie. We dworze zaczęto organizować szpital wojskowy. Jedynie trzy siostry zostały w nim zatrudnione, ale mieszkania musiały szukać poza majątkiem. Dzięki dobroci młynarza zamieszkały we młynie i chodziły do pracy w szpitalu, do dworu ${ }^{31}$.

Gdy w 1941 roku Niemcy wkroczyli na ziemie zajęte przez Rosjan, szpital przestał istnieć. Siostrom udało się jednak zostać. Odzyskały klucze do dworu i przyległych budynków. Na nowo, na miarę możliwości, odżyła wspólnota w Rajcy. Nie trwało to długo. W jedną z lipcowych sobót 1943 roku partyzanci ukrywający się w pobliskich miejscowościach oznajmili siostrom, że trzeba zniszczyć punkty strategiczne, które rzekomo mogłyby posłużyć Niemcom. Zadruku).

${ }^{28}$ APP, Z. Bielawa SAC, Dziedzictwo i odpowiedzialność, z. 3, s. 1, mps. (w przygotowaniu do

${ }^{29}$ APP, Ze wspomnień sióstr, mps.

${ }^{30}$ Bielawa SAC, Dziedzictwo i odpowiedzialność, s. 7-9.

${ }^{31}$ Tamże, s. 9-10. 
liczyli do nich całą posiadłość w Rajcy. Wystraszone siostry zabrały ze sobą tabernakulum z Najświętszym Sakramentem z kaplicy, która na nowo zaistniała w jednym $z$ pomieszczeń dworu, i wybiegły do ogrodu. Trwając tak na modlitwie, czekały na to, co będzie dalej. Partyzanci podpalili oficynę przy dworze, duże budynki gospodarcze i odjechali. Dwór ocalał tylko dlatego, że wiatr odwrócił płomienie w odwrotnym kierunku ${ }^{32}$. Niedługo po spaleniu zabudowań Niemcy wywieźli Siostry do Korelicz i już do Rajcy nie wróciły. Część z nich dostała nakaz wyjazdu do Niemiec. Jednak gdy dotarły do Warszawy, pozostały w jej okolicach. Po wojnie również nie było możliwości powrotu do Rajcy. Zmieniły się granice. Ze wszystkich miejsc pobytu na Wschodzie siostry z repatriantami wyjechały do Polski ${ }^{33}$, pozostawiając już tylko wspomnienia i kilka przedmiotów, które zabrały ze sobą ${ }^{34}$.

W latach powojennych mieściły się we dworze różne instytucje. Przez wiele lat stał również pusty i niszczał. Aktualnie jest w rękach prywatnych. Nowi właściciele, związani ze sztuką i kulturą, powoli odnawiają dwór i zamierzają otworzyć w nim muzeum sztuki ludowej i szkołę pisania ikon.

\section{Architektura}

Pod koniec XVIII wieku bądź na początku XIX wieku ${ }^{35}$, Dunin-Rajeccy wznieśli w Rajcy niewielki dworek jako siedzibę rodową.

Dworek bardzo skromny, aż za skromny, biorąc pod uwagę majątek, jaki posiadali. Ich główną siedzibą było Koszelewo. Tam też nie wznieśli wielkiego pałacu czy dworu, ale skromny dom, może jedynie wygodniejszy od dworu rajeckiego. Nic dziwnego więc, że Rajcy pozostawili skromne oblicze.

32 Tamże, s. 14

${ }^{33}$ Tamże, s. 16-17. W Archiwum Polskiej Prowincji Sióstr Pallotynek przechowywane są również dokumenty repatriacyjne sióstr, które wyjechały z Nowogródka. Jest tam także zaświadczenie o przynależności do Zgromadzenia i świadectwo pracy, które tuż przed wyjazdem 12-13 lipca 1945 roku wystawił ks. Wiktor Kulukas, wcześniejszy proboszcz z Worończy.

${ }^{34}$ Do dzisiaj przechowywane są w Domu Prowincjalnym przedmioty przywiezione z Rajcy, m.in. ornat, kielich mszalny, serwis do kawy. Natomiast w Lidzbarku, w Domu Zgromadzenia znajdują się dwie figury Matki Bożej i św. Józefa, z kaplicy dla wiernych.

${ }^{35}$ Być może na początku XIX w. przeprowadzono gruntowny remont dworku, gdy wznoszono oficynę. Może właśnie taką kolejność należy wziąć pod uwagę? Może kiedyś jeszcze uda się ustalić szczegóły? Może istnieją jakieś nie odkryte źródła? 


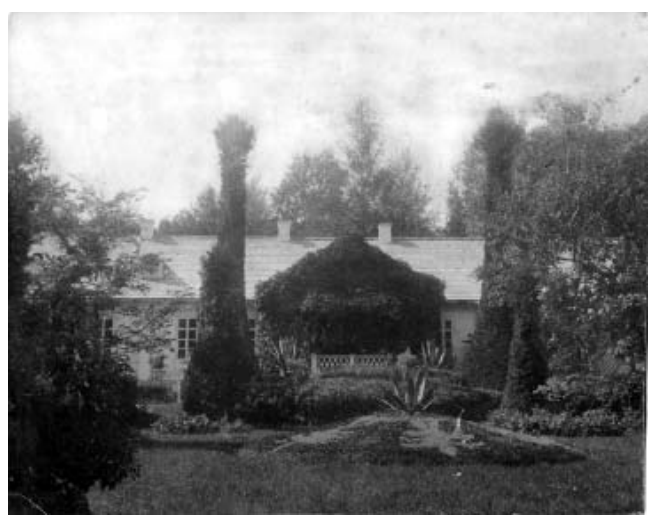

I1.2. Wygląd dworu z czasu, gdy właścicielem był hr. Wawrzyniec Puttkamer, wnuk Maryli, [fot. przechowywana w Archiwum Polskiej Prowincji Sióstr Pallotynek, (W artykule Władysława Slizienia jest umieszczona identyczna fotografia bez podania autora. Być może autorem jest sam W. Slizień)].

Jest to jeden z niewielu drewnianych dworów zachowanych na tych terenach. Ten fakt powoduje, iż warto się nad nim zatrzymać. To typowa ziemiańska siedziba w stylu klasycystycznym. Budynek pański, czy też wielki, był parterowy, dziewięcioosiowy, dwunastoizbowy, drewniany, otynkowany, o dachu dwuspadowym, krytym gontem ${ }^{36}$. W połaciach dachu od frontu znajdowały się dwie lukarny. Pośrodku elewacji frontowej zbudowano ganek - portyk toskański, w którym dwie pary kolumn podpierały trójkątny szczyt ozdobiony rodowym herbem. Dzisiaj pozostał już tylko owalny kartusz herbowy. Do głównego wejścia do dworu prowadziły schody po prawej i lewej stronie kolumnady, oraz furtki w balustradzie z boków. Od frontu ganek był wysunięty do przodu w formie niewielkiego tarasu zamkniętego balustradą ${ }^{37}$.

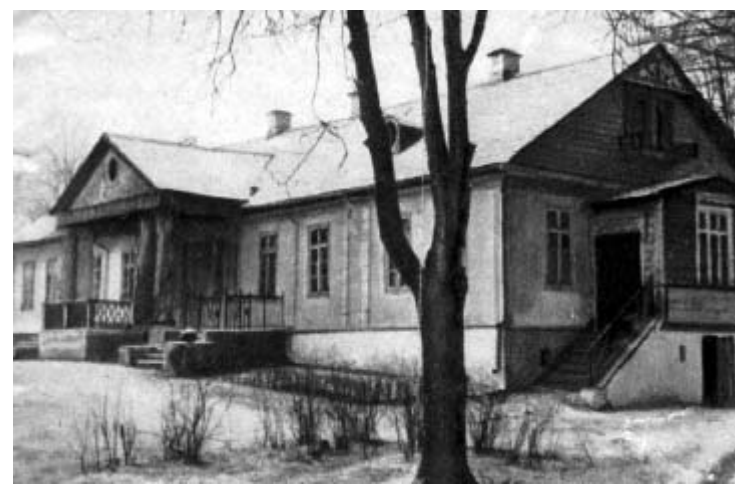

Il.3. Dwór od strony oficyny, wycinek z gazety (?) z albumu S.M. Pauli Moniki Buchwald, Archiwum Polskiej Prowincji Sióstr Pallotynek.

${ }^{36}$ APP, Oświadczenie Wacława Stankiewicza i Mieczysława Konopiołko z 6 lipca 1948 roku.

${ }^{37}$ Wejście zostało zupełnie przebudowane po wojnie. 
Od tyłu, gdzie w większych dworach zwykle znajdował się taras, dostawiono pod kątem prostym trójosiową przybudówkę, również pokrytą dachem gontowym dwuspadowym. W przybudówce znajdowało się wejście do budynku, w narożniku, od strony północno-wschodniej. Gdy mieszkały we dworze siostry, wejście to pełniło rolę furty ${ }^{38}$.

Do ściany szczytowej od strony północno-wschodniej dobudowano małą przybudówkę z wejściem i wąskimi schodami, krytą dachem dwuspadowym. W wysokiej podmurówce przybudówki znajdują się drzwi do pomieszczenia poniżej parteru, małej piwnicy. Nad nią w samym szczycie nad oknem, pomiędzy połaciami dachu znajduje się do dzisiaj motyw dekoracyjny, ażurowa wić akantowa $\mathrm{z}$ kwiatonem.

Do przybudówki z tyłu dworu również dobudowano pomieszczenie kryte dachem pulpitowym $w$ latach 1935-1936 podczas przebudowy dworu przez siostry. W pomieszczeniu dobudowanym z tyłu mieściła się sień i pomywalnia przy kuchni ${ }^{39}$.

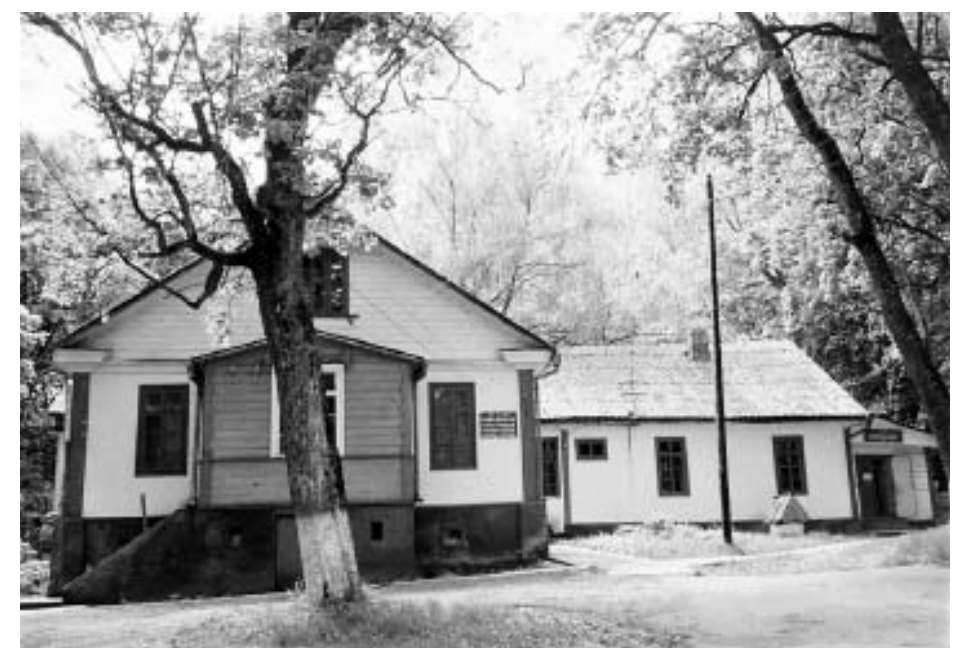

Il.4. Dobudówki od strony parku, fotografia wykonana przez siostry w 1993 r., Archiwum Polskiej Prowincji Sióstr Pallotynek.

Wewnątrz, od głównego wejścia od frontu, znajdował się hall, a po prawej i lewej stronie izby mieszkalne. W pomieszczeniu wewnątrz części frontowej, od na lewo od głównego wejścia w latach 30 . i na początku lat 40. znajdowała się kaplica, którą zaraz po przyjeździe siostry powiększyły ${ }^{40}$.

${ }^{38}$ APP, Ze wspomnień sióstr.

${ }^{39}$ APP, Streszczenie rajczańskich sprawozdań, s. 13.

${ }^{40}$ Z. Soból Z, Pierwsze Pallotynki w Polsce, „Królowa Apostołów”, 28 (1935) nr 3, s. 73-75, (kaplica służyła nie tylko konwentowi, ale również wiernym z pobliskich miejscowości oraz prawosławnym podczas niektórych uroczystości). 


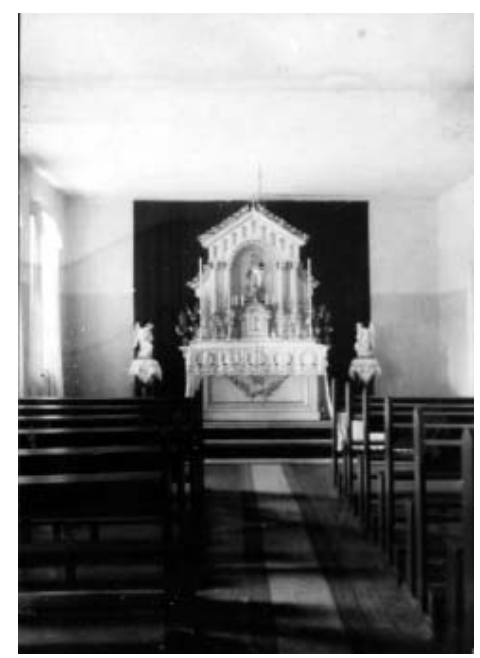

I1.5. Kaplica wewnątrz dworu przed remontem w 1938 r., na lewo od głównego wejścia, z albumu S.M. Pauli Moniki Buchwald, Archiwum Polskiej Prowincji Sióstr Pallotynek.

W kaplicy znajdował się ołtarz drewniany, wykonany i podarowany przez stolarza J. Dąbka z Brodnicy na Pomorzu, jeszcze w 1933 r., gdy bracia pallotyni porządkowali pałac ${ }^{41}$. Jesienią 1938 roku kaplica została pomalowana. Siostra Edyta Czarnowska wykonała też malowidło w kolorze biało-złotym, wić winnej latorośli jako wykończenie okalające kaplicę wokół pod sufitem. Do kaplicy siostry otrzymały figurę Serca Jezusowego w kolorze kremowym od dobrodzieja z Warszawy. Już wcześniej na terenie domu stała figura św. Józefa. Ona też otrzymała podobny kolor i obie stanęly po bokach ołtarza w kaplicy ${ }^{42}$.

Gdy w budynku mieszkały siostry, w części na jego osi od tyłu znajdowała się kuchnia, refektarz, spiżarnia i wspomniana już furta ${ }^{43}$. Całość to ok. $360 \mathrm{~m}^{2}$ powierzchni użytkowej ${ }^{44}$.

W 1936 roku we wnętrzu zostały wprowadzone zmiany. Wówczas rozebrano jedną ze ścian, by powiększyć pomieszczenie, w którym znajdował się refektarz ${ }^{45}$. Także ogromne piece kaflowe i piękne kominki, które ogrzewały dwór, zostały rozebrane. Głównym z powodem takiej decyzji było to, że były przepalone i nie spełniały swojej funkcji. Piece zostały odbudowane z kafli pozyskanych z rozbiórki, ale pomniejszone, a kominki usunięto ${ }^{46}$.

Przy wjeździe do majątku po prawej stronie od bramy pobudowano najprawdopodobniej w XIX wieku empirową, wydłużoną bardzo oficynę, która była uważana za starszą od dworu ${ }^{47}$.

\footnotetext{
${ }^{41}$ A. Majewski, Z Rajcy, „Królowa Apostołów”, 26 (1933) nr 12, s. 331-332.

${ }^{42}$ APP, Streszczenie rajczańskich sprawozdań, s. 30.

${ }^{43}$ APP, Ze wspomnień sióstr.

${ }^{44}$ APP, Oświadczenie Wacława Stankiewicza i Mieczysława Konopiołko.

${ }^{45}$ APP, Streszczenie rajczańskich sprawozdań, s. 13.

${ }^{46}$ Tamże, s. 14.

${ }^{47}$ Aftanazy, Dzieje rezydencji na dawnych kresach, s. 325-326.
} 


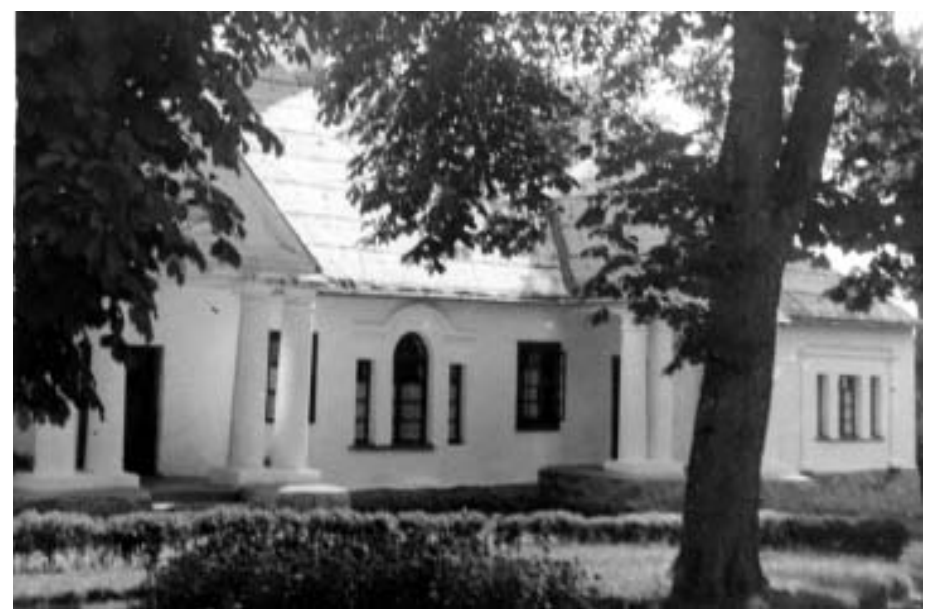

Il.6. Oficyna latem, fotografia z albumu S.M. Pauli Moniki Buchwald, Archiwum Polskiej Prowincji Sióstr Pallotynek.

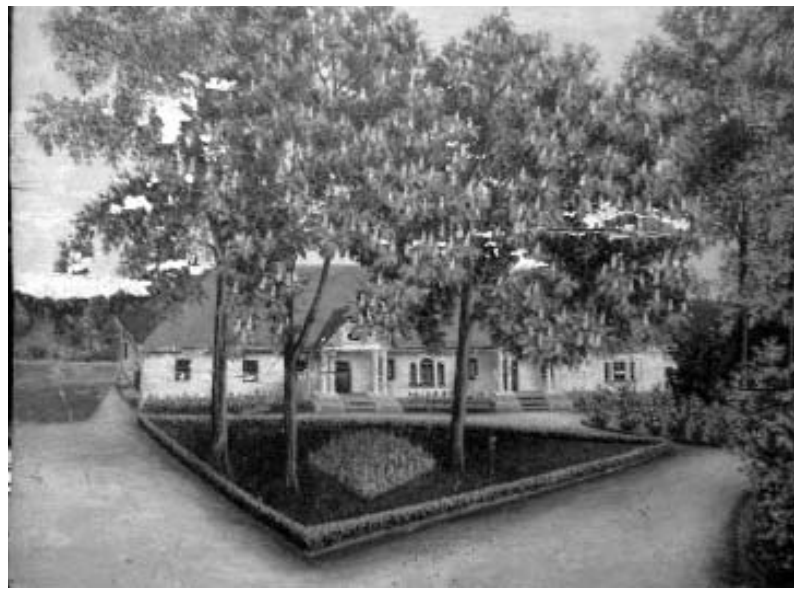

Il. 7. Oficyna, olej na sklejce, malowany przez S. M. Edytę Annę Teresę Czarnowską w 1. 1937-1939, na odwrocie napis: „W dowód wdzięczności za gorliwą i wytrwałą pracę składają Ks. Kapelanowi SS. Pallotynki. Rajca dnia 12. III. 1940 r.”, przechowywany w Archiwum Polskiej Prowincji Sióstr Pallotynek (fot. aut.) .

Do wyjazdu Żółtowskich z Rajcy mieściła się w niej dworska kuchnia. Był to budynek parterowy, dziesięcioosiowy ${ }^{48}$, drewniany, kryty czterospadowym dachem. Podobnie jak dwór kryta gontem. $Z$ dwoma portykami kolumnowymi nawiązującymi do ganku dworskiego i dwoma oknami swym kształtem nawiązującymi do okien dworskiej zabudowy Duninów-Rajeckich w Koszelewie ${ }^{49}$.

${ }^{48} \mathrm{Na}$ zachowanych zdjęciach trudno stwierdzić, ile dokładnie osi posiadała fasada główna oficyny.

${ }^{49}$ Zachowały się również fotografie oficyny w Archiwum Polskiej Prowincji Sióstr Pallotynek. 
Pośród zabudowy w majątku znajdowały się również budynki gospodarcze: stajnia, wozownia, spichlerz, stodoła, dom w ogrodzie, różnego rodzaju pracownie - jak to określały siostry.

Po prawej stronie od dworu za oficyną znajdowała się murowana stajnia z wozownią, a nieco dalej piętrowy spichlerz, o powierzchni $60 \mathrm{~m}^{2}$, do którego przylegała drewniana stodoła ${ }^{50}$. W 1935 roku siostry przebudowały spichlerz na kaplicę dla wiernych. Zgody i poparcia dla tej przebudowy udzielił bp Kazimierz Bukraba, ordynariusz piński ${ }^{51}$.

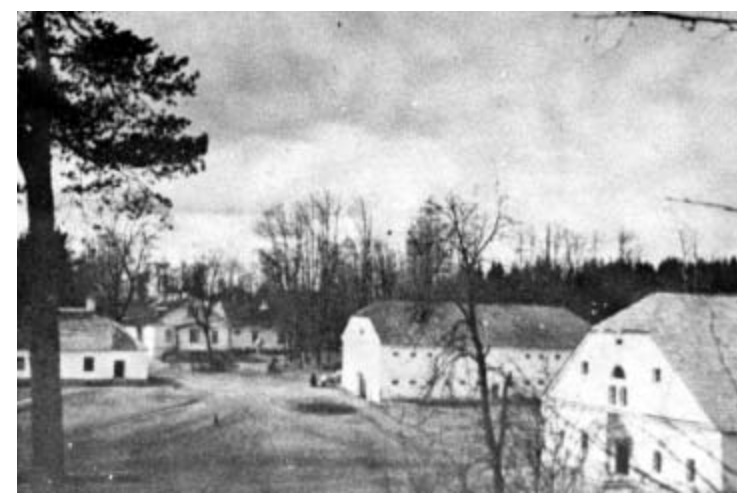

Il.8. Budynki gospodarcze wraz z dworem w Rajcy, fot. z albumu śp. S. Ireny Przybysz, autor nieznany, fot. przechowywana w Archiwum Polskiej Prowincji Sióstr Pallotynek (na pierwszym planie spichlerz, który został przebudowany na kaplicę w 1936 r.).

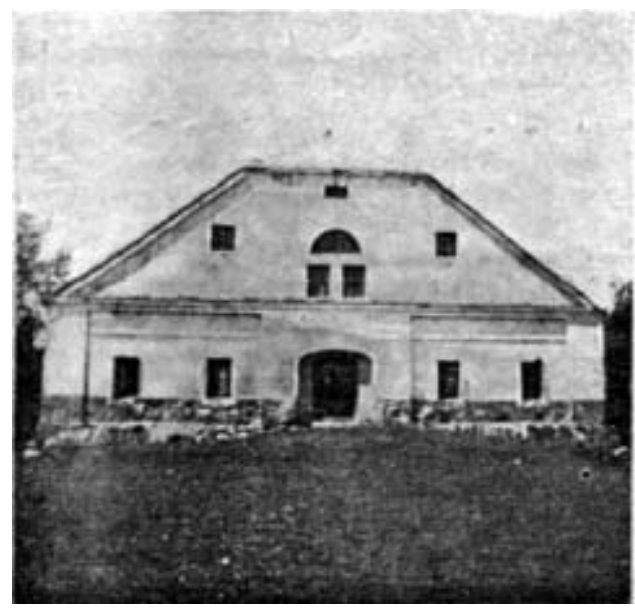

Il. 9. Spichlerz z 1934 r. sprzed przebudowy na kaplicę, fotografia w „Królowej Apostołów”, 1936, nr 9, s. 271, Archiwum Polskiej Prowincji Sióstr Pallotynek.

${ }^{50}$ APP, Oświadczenie Wacława Stankiewicza i Mieczysława Konopiołko.

${ }^{51}$ „Apostoł wśród Świata”, 7 (1936) z. 1, s. 9-12. 
Kaplica stanowiła niejako kościół filialny parafii Worończa, nazywany przez siostry „Misyjny Kościółek”. Prace nad przebudową rozpoczęły się latem. Pozostały dwuskrzydłowe drzwi wejściowe. Dobudowano jedynie drewniany ganek, który miał chronić przed niepogodą. Znajdował się w niej pożyczony 100-letni ołtarz z kościoła farnego w Nowogródku, który był niemym świadkiem chrztu A. Mickiewicza. Był bardzo zniszczony, więc został odnowiony i otrzymał nową kolorystykę, ciemnozieloną ze złoceniamis ${ }^{52}$. Dnia 20 października 1935 roku odbyło się poświęcenie i pierwsza Msza św. w nowej kaplicy ${ }^{53}$. Przed Bożym Narodzeniem tego roku anonimowy ofiarodawca ze Śląska podarował do kaplicy obraz Najświętszego Serca Pana Jezusa ${ }^{54}$. Po jednej i drugiej stronie ołtarza na postumentach ustawione zostały figury Matki Bożej i św. Józefa.

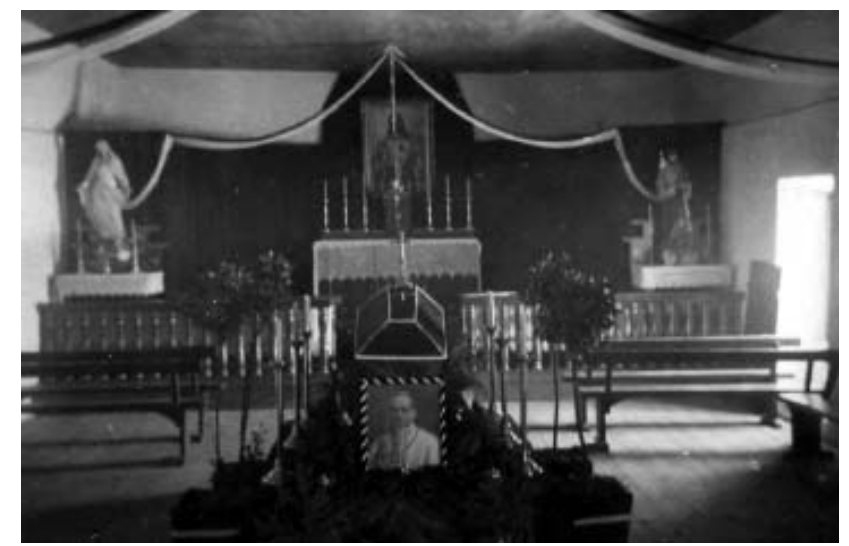

Il.10. Kaplica w dawnym spichrzu z lutego 1939 r., autor nieznany, z albumu S.M. Pauli Moniki Buchwald, Archiwum Polskiej Prowincji Sióstr Pallotynek.

Do przyjazdu sióstr na terenie majątku znajdowała się studnia z żurawiem, oddalona od dworu ok. $100 \mathrm{~m}, \mathrm{z}$ tyłu za oficyną. Z roku na rok zwiększała się liczba mieszkanek, zapotrzebowanie na wodę było większe i ta odległość stawała się pewnym utrudnieniem. W latach 1935-1936 została wykopana nowa studnia tuż przy kuchni, przy wejściu, wyposażona już w wałek z korbą do wyciągania wody ${ }^{55}$.

Za oficyną, w budynkach gospodarczych znajdowały się również: drewutnia, stolarnia, kierat $\mathrm{i}$ inne ${ }^{56}$. Uzupełnieniem budynków dworskich była oranżeria ${ }^{57}$, która prawdopodobnie powstała, gdy właścicielem był Franciszek Wereszczaka, miłośnik ogrodnictwa ${ }^{58}$.

${ }^{52}$ APP, Streszczenie rajczańskich sprawozdań l. 1934-1939, thum. z jęz. niem. Elżbieta Marta Hebel SAC, Gdańsk 1979, mps, s. 10 i n.

${ }^{53}$ APP, T. Bielski SAC, Z ekumenicznej niwy, Otwock, mps.

${ }^{54}$ „Apostoł wśród Świata”, 7 (1936) z. 1, s. 9-12.

${ }^{55}$ APP, Streszczenie rajczańskich sprawozdań, s. 14.

${ }^{56}$ Tamże, s. 4.

${ }^{57}$ Krzywicki pisze o istnieniu oranżerii w: Szlakiem Adama Mickiewicza po Nowogódczyźnie, Wilnie i Kownie. Przewodnik, Prószków 2006, https://books.google.pl/books?isbn=8389188511 (dostęp: 09.04.2018).

${ }^{58}$ Siostry w swoich sprawozdaniach nie wspominają oranżerii. 
W ogrodzie znajdował się jeszcze dom willowy, murowany, sześcioizbowy, o powierzchni $60 \mathrm{~m}^{2}$, który został zniszczony w czasie wojny ${ }^{59}$. Być może ten właśnie domek pierwotnie pełnił rolę oranżerii, może tylko, gdy właścicielem był Franciszek Wereszczaka ${ }^{60}$.

W czasie wojny w 1943 roku spalone zostały oficyna i budynki gospodarcze. Pozostał jedynie dwór otoczony parkiem i słup z herbem Dunin-Rajeckich Łabędź z koroną i łabędziem w klejnocie, na końcu alei w parku ${ }^{61}$.

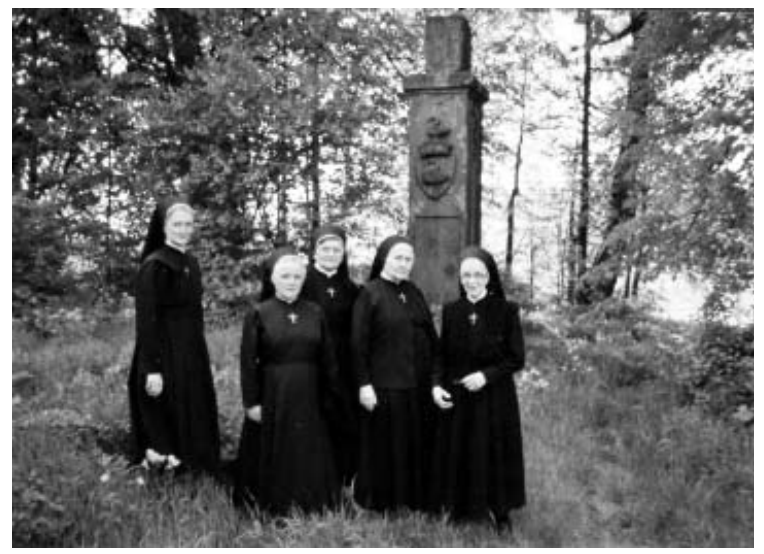

Il.11. Słup kamienny z herbem Dunin - Rajeckich, fotografia wykonana przez siostry podczas pobytu w Rajcy w 1993 r., (Siostry to jedne z ostatnich mieszkanek Rajcy, które po

50 latach zwiedzały pierwszy dom), z albumu S.M. Pauli Moniki Buchwald, Archiwum Polskiej Prowincji Sióstr Pallotynek.

Z tym słupem wiązane są różne historie. Według ustnych przekazów ludności miejscowej słup był związany $\mathrm{z}$ zaginięciem podczas walk $\mathrm{w}$ okolicy jednego z Dunin-Rajeckich. Słup był przedmiotem różnych historii. Według ustnych przekazów miejscowej ludności słup był związany z zaginięciem podczas walk $\mathrm{w}$ okolicy jednego z Dunin - Rajeckich. Być może chodzi tutaj o czasy powstania kościuszkowskiego i potyczkę z oddziałem gen. Łanskoja, o której wspominałam wyżej. Na słupie jest miejsce po tablicy miedzianej, pochodzącej sprzed 1863 roku, którą według przekazów zdjęto po powstaniu styczniowym i zaginęła bezpowrotnie. Na słupie była ustawiona 100-letnia kamienna figura Matki Bożej ${ }^{62}$.

Po II wojnie światowej dwór zmienił swoje oblicze. Przebudowano dach i pokryto go eternitem oraz zlikwidowano lukarny.

${ }^{59}$ Oświadczenie Wacława Stankiewicza i Mieczysława Konopiołko.

${ }^{60}$ Po raz pierwszy w pracy ks. Zygmunty Bielawy spotkałam się z określeniem oficyny w liczbie mnogiej. Być może chodzi o budynek willowy w parku, który w oświadczeniu wymieniają p. Stankiewicz zatrudniony jako zarządca w 1941-1945 i sąsiad p. Konopiołko. Nie wiemy, jak ten budynek wyglądał. Niewiele dowiadujemy się ze źródeł. Być może była to oranżeria, która czasem pojawia się w opisach. Nie mamy jednak żadnej pewności.

${ }^{61}$ Bielawa, Dziedzictwo i odpowiedzialność, s. 14.

${ }^{62}$ APP, Streszczenie rajczańskich sprawozdań, s. 24. (Gdy w marcu 1938 r. zmarła S. M. Czesława Prakseda Malek i została pochowana na cmentarzu założonym obok - na lewo - słupa z herbem Łabędź, jeszcze stała na nim figura Matki Bożej); Aftanazy, Według przekazu autora figura miała pochodzić z kaplicy Szujskich w Warszawie. (Kaplicę rozebrano w 1818 r.) 


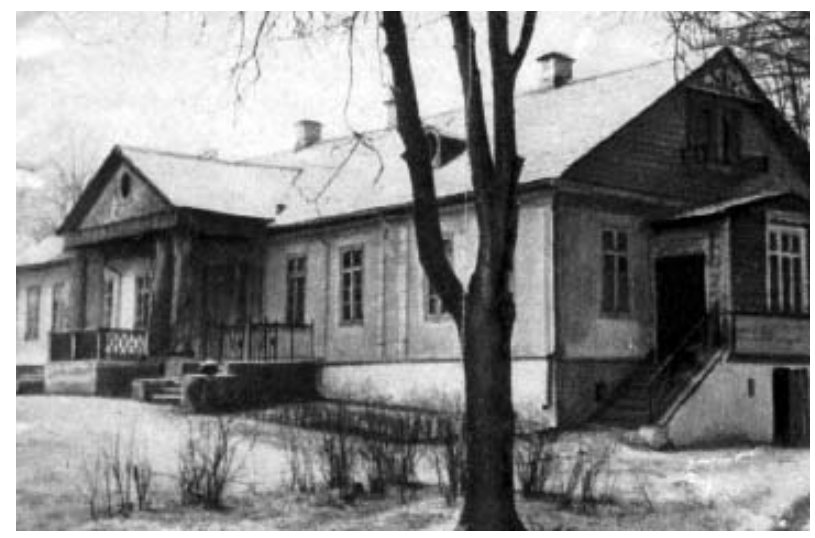

Il. 12. Dwór od strony oficyny, wycinek z gazety (?) z albumu S.M. Pauli Moniki Buchwald, Archiwum Polskiej Prowincji Sióstr Pallotynek

Zmiany wprowadzono również $\mathrm{w}$ ganku. Wyburzone zostały schody, które $\mathrm{z}$ boków kolumnady prowadziły na ganek, a wybudowano nowe, prowadzące na wprost drzwi, pomiędzy pary kolumn. Park został bardzo przerzedzony i niezadbany.

W całym wyglądzie dawna siedziba ziemiańska stała się bardzo skromna i zniszczona.

\section{Park i ogród}

Wokół dworu rozciągały się cztery hektary ziemi, które stanowiły park regularno-krajobrazowy, największa wartość całego majątku, oraz sad i ogród warzywny. Parkowi dodawały uroku aleje lipowe, szpalery, żywopłoty, klomby kwiatowe ${ }^{63}$. Gdy właścicielem Rajcy został Franciszek Wereszczaka, zmienił zupełnie wygląd całej posiadłości. Był z zamiłowania ogrodnikiem, zafascynowanym przyrodą. Odnowił park, wykorzystując stary drzewostan. W przestrzenie pomiędzy drzewami wkomponował piękne klomby. Postarał się o posadzenie wyszukanych gatunków drzew i krzewów. Niektóre formował w ciekawe kształty. Alejki w całym czterohektarowym parku były wysypane drobnym jasnym żwirem i po bokach zabezpieczone kamiennymi rynsztokami ${ }^{64}$.

Wjazd do dworu stanowiła brama murowana i otynkowana na biało, umieszczona na wprost ganku. Od niej do dworu prowadziła aleja lipowa, która wiodła nieco pod górkę, rozchodziła się przed dworem, by otoczyć spory trawnik - gazon, na którym rosły strzyżone tuje i białolistne jesiony. Po zewnętrznej stronie trawnika rosły stare dęby i wyniosły świerk. Na rozrzuconych pomiędzy drzewami klombach kwiatowych zmieniano kwiaty stosownie do pory roku. Z ganku roztaczał się piękny widok przez bramę aż na staw, który znajdował się poza nią ${ }^{65}$.

${ }^{63}$ Samusik, Widok dworu w Rajcy z trzema klombami i wielką agawą na każdym z nich, który utrwalił na swojej akwareli Napoleon Orda. Autorzy artykułu umieszczają krótki opis akwareli.

${ }^{64}$ S. Wierzbica, Na wschodnich rubieżach kraju, „Królowa Apostołów”, 26 (1933) nr 1, s. 2225.

${ }^{65}$ Tamże. 
Po wyjściu z dworu, kierując się w prawo przed pięknie rozrośniętym dębem, rozpoczynał się strzyżony szpaler, który przechodził w szeroką drogę prowadzącą do drugiej bramy. Za nią wychodziło się do kościoła, który stał na pagórku, otoczony lipami ${ }^{66}$.

Z lewej strony dworu ciągnęły się dwa trawniki zakończone żywopłotem, gdzie rozciągał się widok na drugi zadrzewiony pagórek. Wzdłuż drogi ciągnęły się rabaty niskopiennych róż i klomby kwiatowe. W tej części ogrodu rósł piramidalnie rozłożony dąb, płaczący jesion, szereg tui, a przy bramie płaczące wierzby ${ }^{67}$.

$\mathrm{Na}$ osi za dworem znajdowała się jeszcze jedna aleja, którą ujmowały dwa strzyżone szpalery ${ }^{68}$. Na jej końcu znajdował się wspomniany już słup $\mathrm{z}$ herbem Łabędź.

Do dzisiaj, jak mówią obecni właściciele, możemy jeszcze w parku spotkać gatunki drzew, które w naturze nie rosną na tamtych terenach, np.: klony srebrzyste strzępolistne, odmiany Schwedlera, dęby czerwone i piramidalne, jesiony różnego gatunku, a także wierzby białe oraz kruche kuliste ${ }^{69} \mathrm{i}$ inne. Gdy właścicielem Rajcy został Wawrzyniec Puttkamer całe obejście straciło swój blask. Sam właściciel wyprowadził się, a dzierżawcy już nie dbali tak o wygląd domu i całego obejścia. Później przyszły zawirowania wojenne. Taki klimat nie służył ani mieszkańcom, ani posiadłości.

\section{BIBLIOGRAFIA}

\section{Źródla}

Archiwum Polskiej Prowincji Sióstr Pallotynek (APP)

Bielawa Zygmunt Maria SAC, Dziedzictwo i odpowiedzialność, z. 3, mps. (w przygotowaniu do druku)

Bielski Tadeusz SAC, Z ekumenicznej niwy, Otwock, mps.

Oświadczenie Wacława Stankiewicza i Mieczysława Konopiołko z 6 lipca 1948 r., Archiwum Polskiej Prowincji Sióstr Pallotynek.

Streszczenie rajczańskich sprawozdań l. 1934-1939, tłum. z jęz. niem. Elżbieta Marta Hebel SAC, Gdańsk 1979, mps.

Tłumaczenie umowy zawartej pomiędzy Stowarzyszeniem Księży Pallotynów i Zarządem Generalnym Sióstr Pallotynek 5 lipca 1933 r., Archiwum Polskiej Prowincji Sióstr Pallotynek.

Archiwum Domu Księży Pallotynów

Kronika Domu Księży Pallotynów w Ołtarzewie 14-16 czerwca 1933 r.

\section{Opracowania}

Aftanazy Roman, Dzieje rezydencji na dawnych kresach Rzeczypospolitej, t. 2. Województwa brzesko-litewskie, nowogródzkie, Wrocław 1992, s. 325-326.

„Apostoł wśród Świata”, 7 (1935) z. 1, s. 17.

\footnotetext{
${ }^{66}$ Tamże.

${ }^{67}$ Tamże.

${ }^{68}$ Tamże.

${ }^{69}$ Tamże.
} 
„Apostoł wśród Świata”, 8 (1936) z. 1, s. 9-12.

Chmielowski Piotr, Adam Mickiewicz, Zarys biograficzno-literacki, Warszawa 1898.

Co nowego w Domu Misyjnym Sióstr Pallotynek w Rajcy, „Królowa Apostołów”, 29 (1936) nr 9, s. 267-272.

Koronkiewicz-Hupajło Małgorzata, Życie codzienne mieszkańców pałaców i dworów dzisiejszego rejonu solecznickiego $w$ wieku XIX. ,Ze skazanego na zagładę świata. O tem, co ginie i o tych co odeszli”, „Zeszyty Naukowe Koła Wschodnioeuropejskiego Stosunków Międzynarodowych. Monografia Rejonu Solecznickiego", nr 8 (wyd. specjalne), Wrocław, wrzesień 2011.

Scheloske Adelheid SAC, Historia Sióstr Pallotynek Misjonarek - Tabele chronologiczne, Rzym 2016, z. 3.

Soból Zofia, Pierwsze Pallotynki w Polsce, „Królowa Apostołów”, 28 (1935) nr 3, s. 73 75.

Umiastowska Janina „Nałęcz”, Szmat ziemi i życia. Opisy $i$ wspomnienia z przedmowa Czestawa Jankowskiego, Wilno 1928.

Wereszczakówna Maryla, w: Nowa Encyklopedia Powszechna PWN, t. 6, red. B. Petrozolin-Skowrońska, Warszawa 1996, s. 698.

Wierzbica Stanisław, Na wschodnich rubieżach kraju, „Królowa Apostołów”, 26 (1933) nr 1, s. 22-25.

Zielińska Marta, Opowieść o Gustawie i Maryli, czyli Teatr, życie i literatura, Warszawa 1998.

Z naszych domów misyjnych, „Królowa Apostołów”, 26 (1933) nr 11, s. 301-303.

Zwolińska Krystyna, Malicki Zasław, Mały Słownik terminów plastycznych, wyd. 3, Warszawa 1990.

Żółtowska z Puttkamerów Janina, Inne czasy, inni ludzie, Londyn 1998.

Żóltowski Adam (1881-1958), w: Nowa Encyklopedia Powszechna PWN, t. 6, red. B. Petrozolin-Skowrońska, Warszawa 2004, s. 1085.

\section{Netografia}

Chmielowski Piotr, Kobiety Mickiewicza, Słowackiego i Krasińskiego. Zarys literacki, Warszawa 1886, www.edusens.pl/.../wawrzyniec-puttkamer-rywalem-czy-raczej-idolem-mickiewicza (dostęp: 09.04.2018).

Monografia rejonu solecznickiego, „Zeszyty Naukowe Koła Wschodniego Stosunków Międzynarodowych", nr 8 (wyd. specjalne), Wrocław, wrzesień 2011, www.kwsm. uni.wroc.pl/dokumenty/ZNS8.pdf (dostęp: 09.04.2018).

Poczet posłów z woj. Nowogródzkiego i Lidzkiego itp. https://books.google.pl/books?itd=5glfAAAAcAAJ (dostęp: 09.04.2018).

Slizień Władysław, Przeczytajmy to jeszcze raz. Wieś Ilustrowana - u kolebki wieszcza, „Wieś Ilustrowana”, (1911) nr 9, http://cbr.gov.pl/rme-archiwum/2010/rme37/ dane/9_4.html (dostęp: 09.04.2018).

Związek Rōu Żółtowskich, Adam Żółtowski/1881-1958/, „Kwartalniki”, (1995) nr 6-8, 1 czerwca, www.zoltowscy.pl/wp/1995/06/adam-zoltowski-1881-1958/, (dostęp: 09.04.2018). 


\section{A MANOR HOUSE COMPLEX IN RAJCA: A MONOGRAPHIC AR- TICLE ON THE HISTORY OF THE POLISH PROVINCE OF THE PALLOTTINE MISSIONARY SISTERS OF THE CATHOLIC APOSTOLATE}

\section{Summary}

The article presents a manor house complex situated in the picturesque village of Rajca, between Nowogródek and Baranowicze, in present-day Belarus. The village belonged to the Dunin-Rajecki family from Koszelewo. They built a classicist manor house and outbuildings in the eighteenth and nineteenth centuries. The manor house was surrounded by four hectares of land on which there were formal and landscape gardens, an orchard and a vegetable garden. Franciszek Dunin - Rajecki's daughter, Ludwika - inherited Rajca and brought it as a dowry to the Wereszczaka family when she married Józef, the younger brother of Adam Mickiewicz's adolescent love, Maryla. A complete refurbishment of the manor is connected with this marriage in the mid-nineteenth century.

In the second half of the 19th century another owner, Franciszek Wereszczaka, transformed the old tree stand around the manor into beautiful formal and landscape gardens, which became the most valuable assets of the entire estate. Together with the orchard and the vegetable garden, they covered four hectares of land. After Franciszek's death, Rajca was taken over by the Puttkamer and Żółtowski families. The last owner, Count Adam Żółtowski (a professor of philosophy at the University of Poznań), bestowed his estate on the Pallottine Priests, and they sold it to the Pallottine Sisters, who had this estate in their possession until they were removed from it by the German army in 1943.

It is a typical Polish classicist manor house, one of only a few wooden ones which survived in these areas. In the nineteenth century, at the entrance to the estate, on the right of the gate, there was probably an extended Empire outbuilding, which was considered to be older than the manor. There were also other outbuildings in the estate: a stable, a coach house, a granary, a barn, and a house in the garden. They all were burnt down during the war in 1943. The only things that remained were a ruined and slightly rebuilt manor house surrounded by the destroyed gardens, and a stone pillar (at the end of the avenue in the park) with the Dunin-Rajecki coat of arms, Łabędź, including a depiction of a crown and a swan.

Key words: Rajca; Nowogródek; the Pallottine Sisters; the Pallottine Priests; the Dunin-Rajecki family 